\title{
INITIAL GROWTH OF PHYSIC NUT AS A FUNCTION OF SOURCES AND DOSES OF ORGANIC FERTILIZERS
}

\author{
Crescimento inicial de pinhão manso em função de fontes e doses de adubos orgânicos
}

\author{
Deisinara Giane Schulz' ${ }^{1}$ Rubens Fey², Viviane Ruppenthal' \\ Marlene de Matos Malavasi'2, Ubirajara Contro Malavasi ${ }^{2}$
}

\begin{abstract}
Organic fertilization provides low cost, supplemental nutrition for plant production. This study aimed to determine the best source and dose of organic fertilizer on the growth of physic nut (Jatropha curcas L.), a potential biodiesel producer. Physic nut seedlings were transplanted to $18 \mathrm{dm}^{3}$ black plastic pots filled with soil mixed with four sources of organic fertilizer (chicken, fish, cattle manure or urban waste compost) at four dose levels $\left(50,100,200\right.$ or $\left.400 \mathrm{~L} \mathrm{~m}^{-3}\right)$. Fertilized and control (no fertilization) plants were grown under shadehouse conditions and morphological plant features were assessed at 30, 60, 90 and 120 days after transplanting. Doses higher than $100 \mathrm{~L} \mathrm{~m}^{-3}$ of poultry manure mixed with claysoil should be avoided. The use of other sources such as cattle manure, fish manure and composting may be used and result in increase in height, leaf area, SPAD index up to doses of $200 \mathrm{~L} \mathrm{~m}^{-3}$ manure mixed in clay soil.
\end{abstract}

Index terms: Organic fertilization, Jatropha curcas L., seedling production.

\section{RESUMO}

A adubação orgânica permite o suprimento nutricional de uma cultura com baixos custos para a produção. Este trabalho objetivou determinar a melhor fonte e dose de adubos orgânicos no crescimento inicial de Jatropha Curcas L. Mudas de pinhão manso foram transplantadas para vasos de plásticos de $18 \mathrm{dm}^{3}$ de volume preenchidos com solo peneirado e misturado com quatro fontes

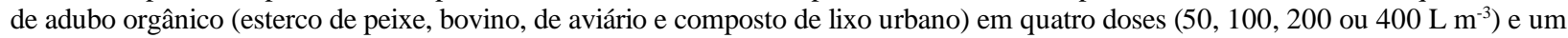
tratamento sem adição de adubo, avaliadas aos 30,60,90 e 120 dias após o transplantio das mudas nos vasos. Doses superiores a 100 $\mathrm{L} \mathrm{m}^{-3}$ de esterco de frangos misturados com solo argiloso para adubação de mudas de pinhão-manso devem ser evitadas. $\mathrm{O}$ uso de outras fontes, como esterco bovino, esterco de peixes e compostagem podem ser utilizadas e resultam em incremento de em altura, área foliar, índice SPAD, até doses de $200 \mathrm{~L} \mathrm{~m}^{-3}$ do dejeto misturados em solo argiloso.

Termos para indexação: Adubação orgânica, Jatropha curcas L., produção de mudas.

\section{(Received in august 27, 2012 and approved in november 21, 2012)}

\section{INTRODUCTION}

Physic nut (Jatropha curcas L. - Euphorbiaceae) is a perennial, deciduous shrub which produces crops of oil-rich nuts (OPENSHAW, 2000). Recently, nuts have been targeted for use in biodiesel production as a replacement for conventional diesel (SUBRAMANIAN et al., 2005).

J. curcas is considered adaptable to many climatic and edaphic conditions (ARRUDA et al., 2004), yet soil nutrient availability causes high variation in fruit production. Furthermore, Jatropha extracts high amounts of nutrients during the fructification process, reducing soil fertility (LAVIOLA; DIAS, 2008) and limiting the ability of the species to provide consistent nut crops for biodiesel.
Fertilization is recommended to increase soil nutrient levels to the target culture requirements or replenish nutrients extracted by crop production (NOVAIS; SMYTH; NUNES, 2007). Synthetic fertilizers are expensive, while animal manure has become an attractive, low cost alternative for small farmers (SOBRINHO et al., 2009).

Crop dose recommendations vary with the initial soil type, organic compound applied, and environmental conditions. Type of organic fertilizer and nutrient composition varies according to different Brazilian regions. The nutrient source used depends on the cost per unit of element, because it has no toxic component to plants.

In cities with selective garbage collection and composting production, Ruppenthal and Castro (2005) concluded that fertilization with compost favors physical,

\footnotetext{
'Universidade Estadual do Oeste do Paraná/UNIOESTE - Rua Pernambuco - 1777 - Cx. P. 91 - 85960-000 - Marechal Cândido Rondon - PR - Brasil deisi_gs@hotmail.com

'Universidade Estadual do Oeste do Paraná/UNIOESTE - Marechal Cândido Rondon - PR - Brasil

${ }^{3}$ Universidade Federal do Ceará/UFC - Departamento de Fitotecnia - Fortaleza - CE - Brasil
}

Ciênc. agrotec., Lavras, v. 36, n. 6, p. 615-623, nov./dez., 2012 
chemical and biological soil properties. In rural areas, manure is readily available and some manure-based organic sources have been tested for crops including: soybeans, corn, pastures and vegetables (SAMPAIO et al., 2007).

For the production of physic nut seedlings in small plugs waste compost mixed with subsoil (LIMA et al., 2011), or manure and chicken waste mixed with soil (CAMARGO et al., 2011) were suggested at doses of up to $60 \%$ during the nursery stage. The potential use of organic sources in physic nut cropping can increase productivity with reduced costs relative to conventional fertilizer, resulting in increased farm income.

This study compared the effects of source and dose of organic fertilizers on the initial growth of physic nut seedlings in order to determine ideal dose levels for readily available fertilizers.

\section{MATERIAL AND METHODS}

The experiment was conducted from March to August 2010 in Marechal Cândido Rondon - Paraná - Brazil with seedlings grown from seeds produced in Dourados Mato Grosso do Sul using $120 \mathrm{~cm}^{3}$ conical containers filled with commercial substrate (Plantmax Florestal ${ }^{\circledR}$ ) composed of pine bark, expanded vermiculite and peat (NPK 4:20:6) and $4 \mathrm{~kg} \mathrm{~m}^{-3}$ of NPK at 10-10-10 formulation (GONÇALVES et al., 2005). Forty-five days after germination, plantlets were transferred to $18 \mathrm{~L}$ plastic pots filled with a local soil mixed with organic fertilizers passed through a $5 \mathrm{~mm}$ mesh sieve. Pots were irrigated daily to near saturation, kept in a shadehouse, randomized treatments monthly in blocks to eliminate shadehouse microsite variations and cultivated for a period of 120 days.

Native soil was classified as an Oxisol of loamy texture (EMPRESA BRASILEIRA DE PESQUISA AGROPECUÁRIA-EMBRAPA, 1999) corresponding to a Rhodic Eutrudox (UNITED STATES DEPARTMENT OF AGRICULTURE-USDA, 1996). Clay, silt, sand, and organic matter content were: $685 \mathrm{~g} \mathrm{~kg}^{-1}, 210 \mathrm{~g} \mathrm{~kg}^{-1}, 105 \mathrm{~g} \mathrm{~kg}^{-1}, 21.44$ $\mathrm{g} \mathrm{dm}^{-3}$, respectively. Exchangeable bases were: $\mathrm{Ca} 5.06$ $\mathrm{cmol} \mathrm{dm}^{-3}, \mathrm{Mg} 1.69 \mathrm{cmol} \mathrm{dm}^{-3}, \mathrm{~K} 1.07 \mathrm{cmol} \mathrm{dm}^{-3}, \mathrm{Al} 0.10$ $\mathrm{cmol}_{\mathrm{c}} \mathrm{dm}^{-3}, \mathrm{P} 40.82 \mathrm{mg} \mathrm{dm}^{-3}$, potential acidity $\mathrm{H}+\mathrm{Al} 5.15$ $\mathrm{cmol}_{\mathrm{c}} \mathrm{dm}^{-3}, \mathrm{pH} 4.6$ and the following physic-chemical properties were: SB $7.83 \mathrm{cmol}_{c} \mathrm{dm}^{-3}$, CTC $12.98 \mathrm{cmol}_{c} \mathrm{dm}^{-3}$ and V $60.31 \%$. Micronutrients values corresponded to $\mathrm{Cu}$ $15.10 \mathrm{mg} \mathrm{dm}^{-3}, \mathrm{Mn} 444.0 \mathrm{mg} \mathrm{dm}^{-3}, 123.0 \mathrm{mg} \mathrm{Fe} \mathrm{dm}^{-3}$ and $\mathrm{Zn}$ $6.7 \mathrm{mg} \mathrm{dm}^{-3}$.

Seedling morphometric measurements consisted of increments in height (IH) from the base to the first node, stem diameter (ID), leaf chlorophyll with a chlorophyll meter
(SPAD-502), number of leaves (NL), leaf area (LA) as suggested by Severino, Do Vale and Beltrão (2007), and seedling root volume $\left(\mathrm{cm}^{3}\right)$ obtained by measuring the volume of displaced water with a graduated cylinder. Daily temperature measurements were obtained from a nearby meteorological station.

The sources of organic fertilizers were poultry manure obtained from ten chicken batches, cattle manure, fish manure and urban waste compost. The experimental design was a block in a factorial scheme ( $5 \mathrm{x} 4)$, consisting of the four organic fertilizers at five dose levels $(0,50,100$, 200 and $400 \mathrm{~L} \mathrm{~m}^{-3}$ ), with four replicates of one pot per combination of fertilizer and dose level. Seedlings were quantified at 30, 60, 90 and 120 days after transplanting (DAT).

Total amount of nutrients from organic fertilizers (Table 1) were extracted by a sulfuric acid digestion for nitrogen, a nitro-perchloric acid for the other nutrients, and carbon content determination followed recommendations of Tedesco et al. (1995). The $\mathrm{C} / \mathrm{N}$ ratio was 7.18, 6.14, 6.76 and 3.38 respectively for poultry manure (PM), cattle manure (CM), waste composting (WC), and fish composting (FC).

Significant differences among fertilizer type and dose combinations were detected using ANOVA at the $\alpha=$ 0.05 level and mean comparison used Tukey's HSD with adjustments for regression equations and polynomial response surface for doses of fertilizers organics and DAT using the statistical program Genes (CRUZ, 2006). Maximum efficiency calculation for each variable measured used the methodology described by Storck, Garcia and Lopes (2000).

\section{RESULTS AND DISCUSSION}

The interaction between DAT and fertilizer dose explained by the response surface regression showed an increase or maintenance of NL (Figure 1) and LA (Figure 2) with increasing fertilizer dose even under low temperature $\left(2^{\circ} \mathrm{C}\right.$ in July) at the experimental site (Figures 1 and 2 ).

An increase in the dose of fish manure, cattle manure and urban waste compost resulted in an increase in leaf number whereas poultry manure induced a reduction with increased dose (Figure 1).The number of leaves on seedlings that received cattle and fish manure expressed a linear increase on DAT and dose without reaching a tested maximum. Seedlings fertilized with poultry manure (PM) reached maximum NLat a dose of $160.8 \mathrm{Lm}^{-3}$. With the PM compost in the substrate it was not possible to calculate the optimal dose for fertilization. 
Table 1 - Total amount of nutrients from organic fertilizers.

\begin{tabular}{lrrrr}
\multicolumn{1}{c}{ Source } & FC & CM & PM & WC \\
\hline & \multicolumn{3}{c}{$\mathrm{g} \mathrm{kg}^{-1}$} \\
Nitrogen (N) & 6.00 & 16.00 & 45.90 & 9.30 \\
Phosphorus (P) & 2.68 & 3.47 & 12.61 & 1.79 \\
Potassium (K) & 0.69 & 3.16 & 25.63 & 1.87 \\
Calcium (Ca) & 32.57 & 33.69 & 61.20 & 41.59 \\
Magnesium (Mg) & 7.01 & 6.52 & 12.56 & 6.31 \\
& & & $\mathrm{mg} \mathrm{kg}^{-1}$ & \\
Copper (Cu) & 289.82 & 355.33 & 249.08 & 325.01 \\
Manganese (Mn) & 556.09 & 1498.97 & 1248.40 & 1234.40 \\
Zinc (Zn) & 183.09 & 320.96 & 863.23 & 160.09 \\
Iron (Fe) & 118.48 & 148.34 & 44.64 & 128.32 \\
\hline
\end{tabular}

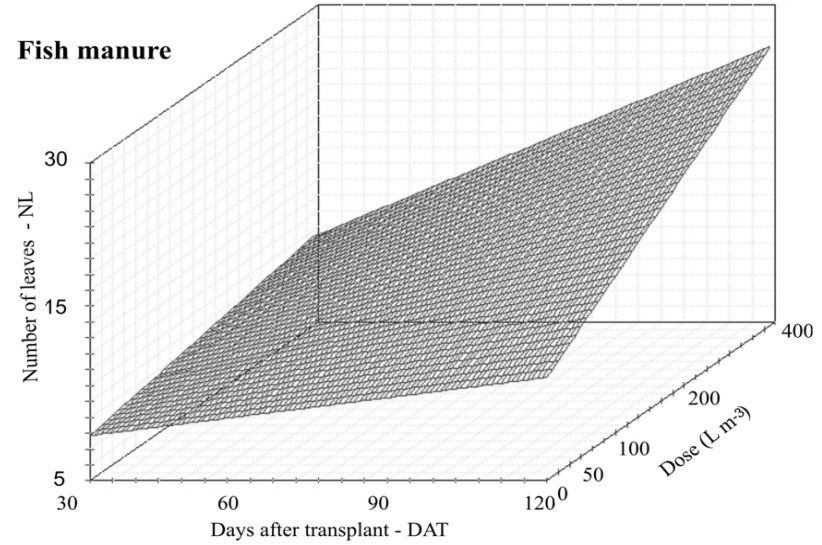

$\mathrm{NL}=6,8750+0,04679 \mathrm{DAT}-0,00001$ Dose + 0,00027DATDose

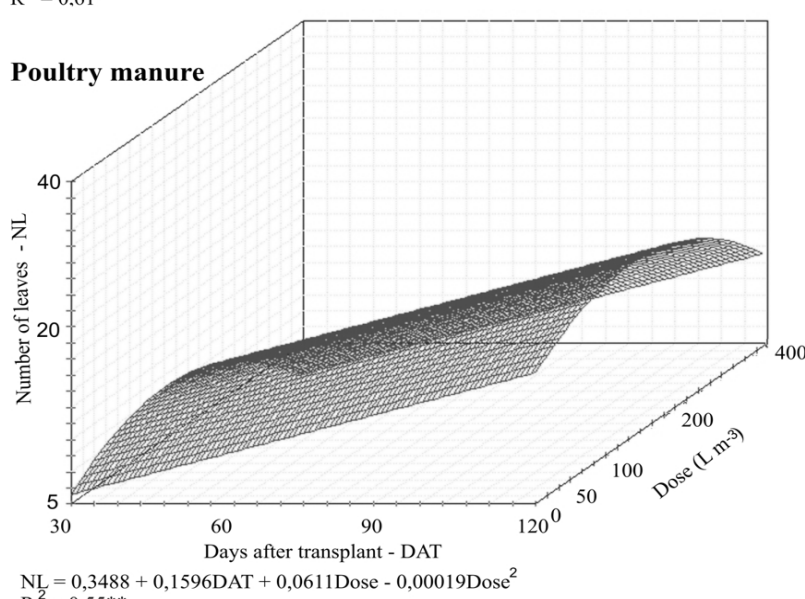
$\mathrm{NL}=0,3488+0,1596 \mathrm{DAT}+0,0611$ Dose $-0,00019$ Dose $^{2}$
$\mathrm{R}^{2}=0,55^{* * *}$

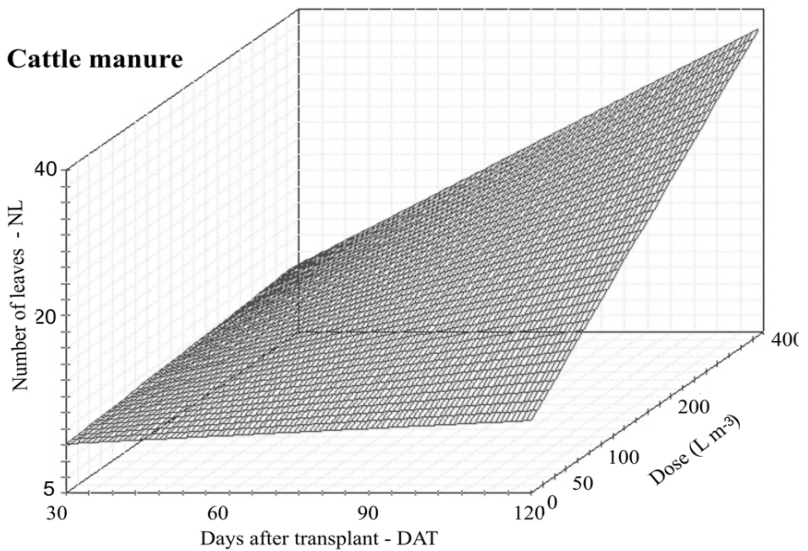

$\mathrm{NL}=9,4126+0,0272 \mathrm{DAT}-0,0142$ Dose $+0,00064$ DATDose $\mathrm{R}^{2}=0.74 *$

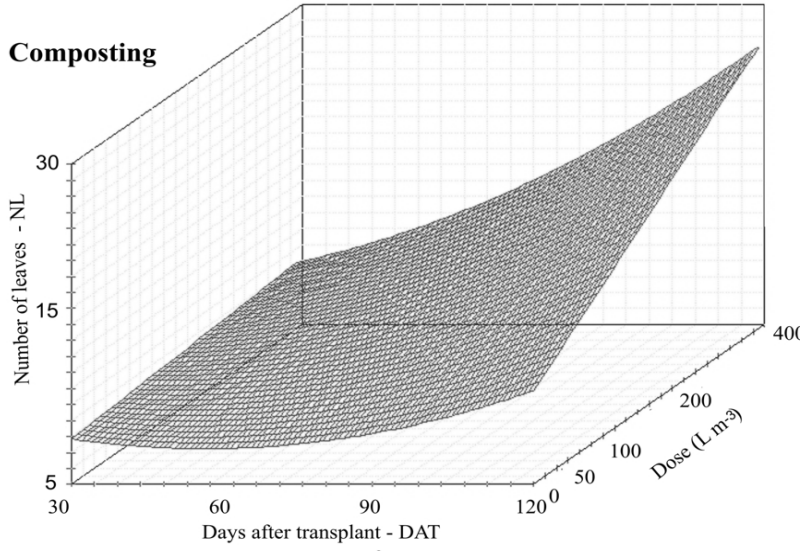

$\mathrm{NL}=11,2938-0,1245 \mathrm{DAT}-0,0011 \mathrm{DAT}^{2}-0,0071$ Dose $+0,00037 \mathrm{DATDose}$
$\mathrm{R}^{2}=0,78^{*}$

Figure 1 - Number of leaves (NL) in physic nut seedlings as function of days after transplant (DAT), type of, and dose level for fish manure, cattle manure, poultry manure and urban waste compost.

Ciênc. agrotec., Lavras, v. 36, n. 6, p. 615-623, nov./dez., 2012 


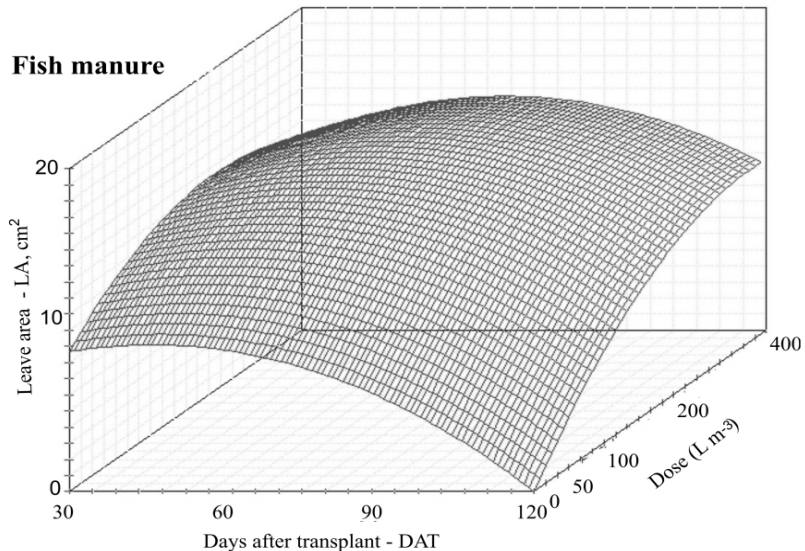

$\mathrm{LA}=5.8384+0.1612 \mathrm{DAT}-0.0017 \mathrm{DAT}^{2}-0.0334 \mathrm{Dose}^{2}-0.00008 \mathrm{Dose}^{2}+0.0002$ DATDose

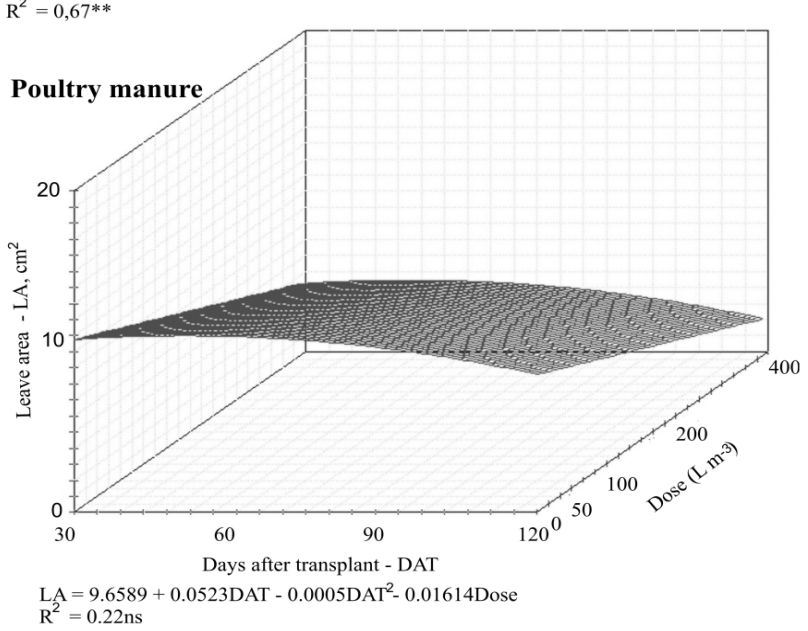

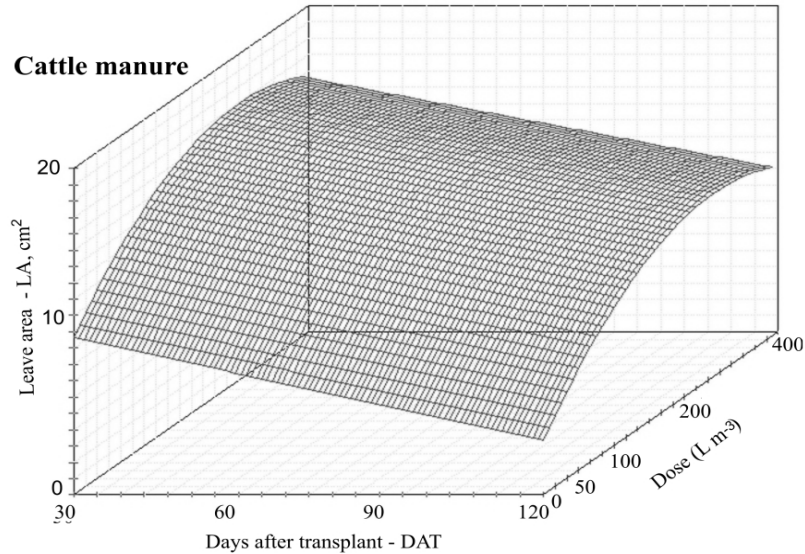

LA $=13.5111-0.0875 \mathrm{DAT}+0.0593$ Dose -0.0001 Dose $^{2}+0.00002$ DATDose

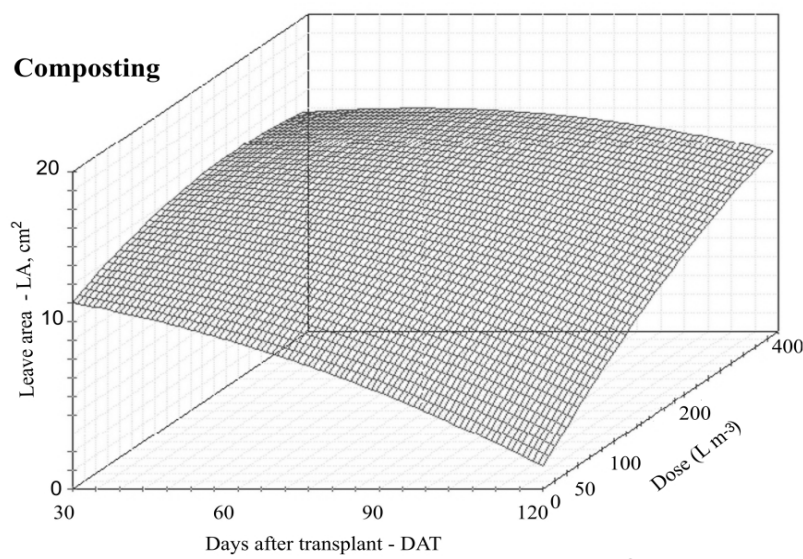

$\mathrm{LA}=11.1714-0.0227 \mathrm{DAT}-0.0005 \mathrm{DAT}^{2}+0.0105$ Dose $-0.00003 \mathrm{Dose}^{2}+0.0002 \mathrm{DATDose}$
$\mathrm{R}^{2}=0.61^{*}$

Figure 2 - Physic nut seedling leaf area (LA) as function of days after transplanting (DAT) and doses of organic fertilizer for fish manure, cattle manure, poultry manure and urban waste compost.

Seedlings that received FM and WC showed quadratic behavior for DAT and doses, with maximum points at 63 and $26 \mathrm{DAT}$ and doses of $292 \mathrm{~L} \mathrm{~m}^{-3}$ and $260 \mathrm{~L}$ $\mathrm{m}^{-3}$ respectively, favoring larger leaf areas. The use of CM resulted in a linear decrease for DAT and a quadratic increase for doses, with optimal dose estimated at $269 \mathrm{~L}$ $\mathrm{m}^{-3}$. For $\mathrm{PM}$ there was no significant $(\mathrm{P}>0.05)$ equations (Figure 2).

A decrease in leaf area of physic nut seedlings resulted from mean minimum temperatures of 13.1, 12.2 and $12.6^{\circ} \mathrm{C}$ during June, July and August, respectively. Low temperatures induce leaf shedding in physic nut (SATURNINO et al., 2005).

With respect to chlorophyll concentration expressed by the SPAD index, physic nut leaves showed linear increase as a function of seedling DAT grown in soil with catle manure, while the other treatments resulted in a curve with maximum points at approximately 120 DAT (Figure 3). Optimum doses of fertilizer were estimated at $295 \mathrm{~L} \mathrm{~m}^{-3}$ for CM, $22 \mathrm{~L} \mathrm{~m}^{-3}$ for PM, and $302 \mathrm{~L}$ $\mathrm{m}^{-3}$ for WC. Poultry manure had the lowest maximum dose, possibly as a result of adequate supply of nutrients provided by poultry manure to seedlings grown in soil with doses from 100 to $200 \mathrm{~L} \mathrm{~m}^{-3}$ and toxicity effects by excess, especially $\mathrm{N}$ in the high doses.

The determination of chlorophyll concentration can predict the nutritional level of nitrogen $(\mathrm{N})$ in plants (PIEKIELEK; FOX, 1992; SMEAL; ZHANG, 1994). Fish manure resulted in a linear increase in relation to the addition of this fertilizer (Figure 3). 

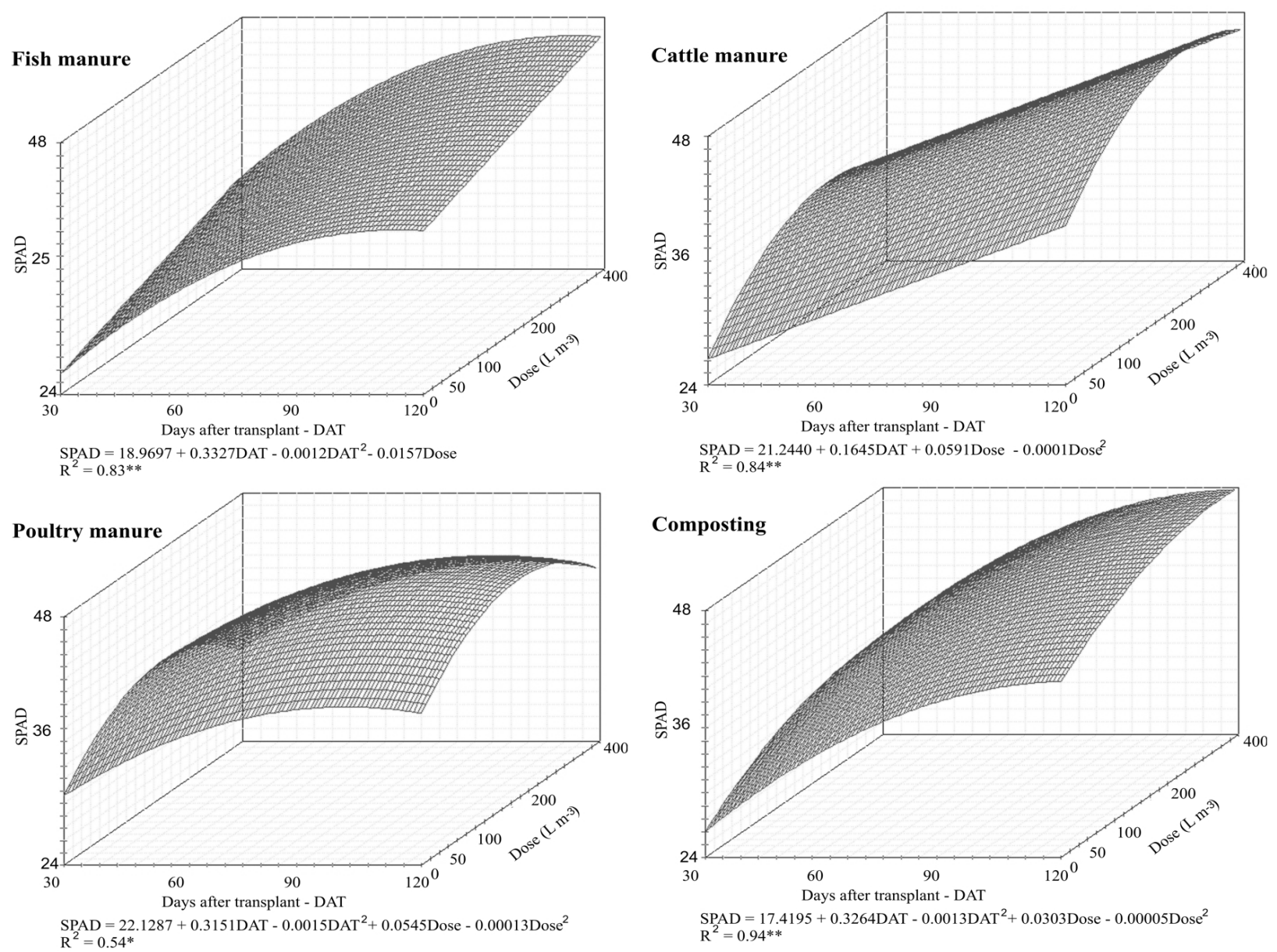

Figure 3-SPAD index in seedlings of physic nut as function of days after transplanting (DAT) and doses for fish manure, cattle manure, poultry manure and urban waste compost.

Organic fertilization regardless of source resulted in differences in relation to the control treatment in the measured variables. The improvement of soil quality, especially in regard to the chemical composition, may have promoted these effects. However, increments compared to the control occurred in soil with high levels of $\mathrm{P}, \mathrm{Ca}, \mathrm{Mg}, \mathrm{K}$ and $\mathrm{V} \%$ for most crops (TOMÉ JÚNIOR., 1997).

The results obtained in this experiment do not correlate with those that suggested physic nut can be grown in soils with low nutrient supply (ARRUDA, 2004; TOMINAGA, 2007). The root volume of physic nut seedlings showed variation in relation to the fertilizer source used (Figure 4). Cattle manure induced a linear increase in root volume implying that the maximum dose for cattle manure was not reached in levels tested.
Contrary results were obtained in seedlings fertilized with poultry manure which expressed small root volume, especially at doses of 200 and $400 \mathrm{~L} \mathrm{~m}^{-3}$. The available $45 \mathrm{~g} \mathrm{~N} \mathrm{~kg}^{-1}$ an amount which is considered high compared to a published dose of $35 \mathrm{~g} \mathrm{~kg}^{-1}$ by Oleynik et al. (1995) coupled with a low C/N (7.18) probably resulted in fast mineralization. According to Fernandes (2006), excess $\mathrm{NH}_{4}$ absorption interferes with water balance and root growth, among other deleterious effects to plant metabolism. Whereas the poultry manure was partially stabilized, the continuing process of maturation probably occurred in the seedling substrate.

Sediyama et al. (2008) described that manure which is not heat stable can inhibit root elongation and consequently reduce plant dry matter production by lowering water and nutrient absorption. These factors 
may have reduced number of leaves, leaf area and root volume of seedlings grown in soil with poultry manure with more than $100 \mathrm{~L} \mathrm{~m}^{-3}$ (Figures 1, 2 and 4). Fish manure and waste composting yielded no significant equations.

The increase in physic nut seedling height from 30 to 120 DAT in $18 \mathrm{~L}$ pots showed a quadratic adjustment for seedlings that received cattle manure and urban waste composting with a maximum increase estimated at 30 DAT. The estimated point of maximum technical efficiency for fertilizer dose was $254 \mathrm{~L} \mathrm{~m}^{-3}$ with fish manure. There was linear increase with soil plus manure or composting, whereas with the addition of poultry manure there was a linear decline not responding positively to fertilization doses and DAT, possibly resulting from the toxic effects described above (Table 2).

Severino, Lima and Beltrão (2006) suggested the use of soil mixed with equal parts of cattle manure, rice husks, and agave mucilage for production of physic nut seedlings. The same authors emphasized that the above fertilizers can provide adequate conditions using either plastic bags or

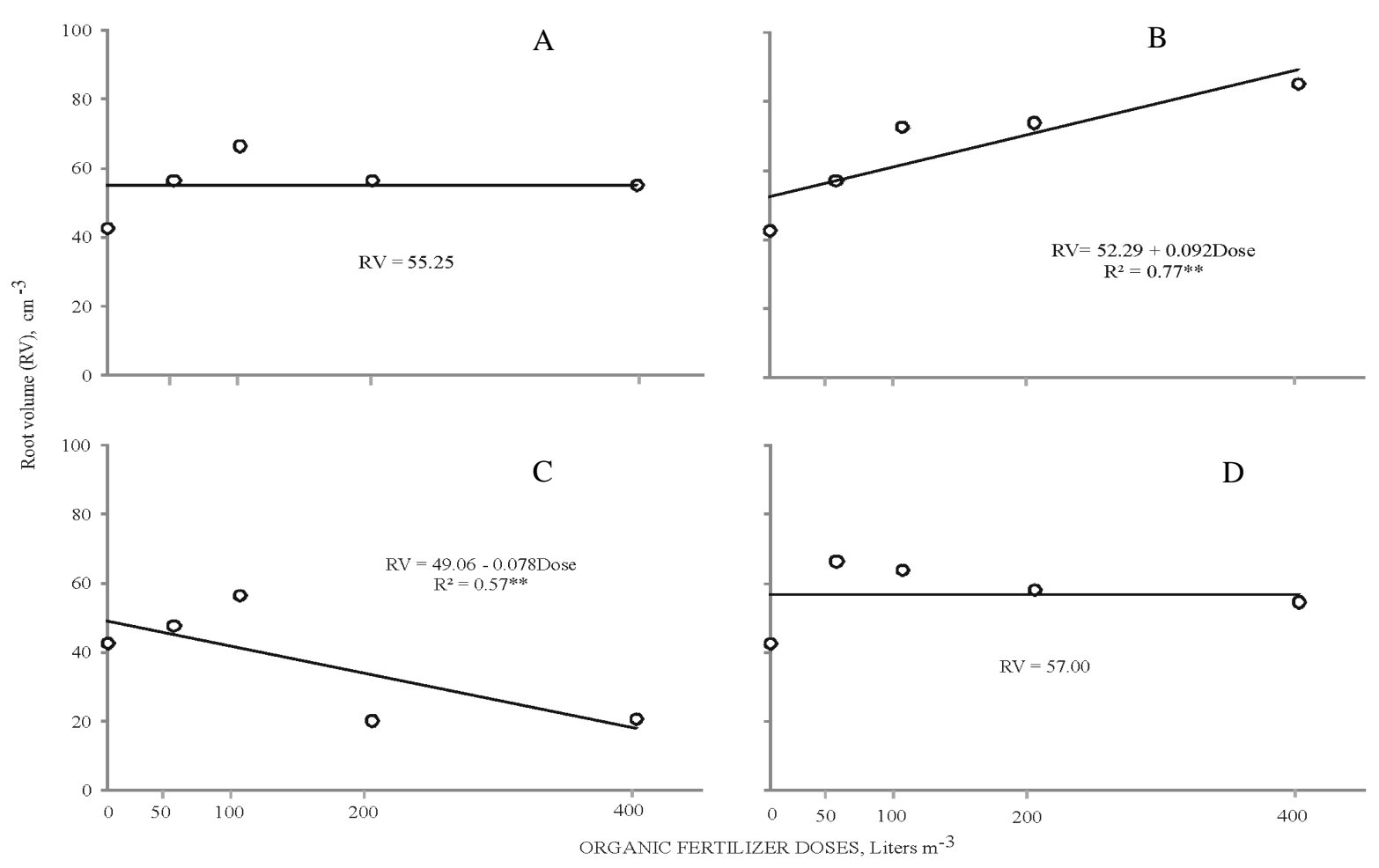

containers. Seedlings conducted on a substrate formed by soil plus fish manure, urban waste compost, or cattle manure showed the highest values for increase of stem diameter. The estimated maximum point for fish manure dose was 165 $\mathrm{L} \mathrm{m}^{-3}$ while there was a linear increase on stem diameter with the use of cattle manure and composting. The maximum increase in stem diameter was reached at approximately 71 DAT for all fertilizers tested.

The mixture of soil and poultry manure resulted in a straight line independent of the doses (Table 2). Lima et al. (2006) evaluating the use of chicken manure as organic fertilizer on the growth of castor seedlings, found that poultry litter proved to be a chemically active organic source, but poor from the physical point of view. The highest values for height and stem diameter increments resulted from using cattle manure at 200 and $400 \mathrm{~L} \mathrm{~m}^{-3}$, followed by those measured in seedlings that received fish manure and composting. The lowest values were measured in seedlings with addition of poultry manure at the same doses (Table 2).

Figure 4 - Root volume (RV) in seedlings of physic nut as a function of doses of different sources of organic fertilizer. (A) Fish manure $\mathrm{F}=0,927^{\mathrm{ns}}$, (B) Cattle manure $\mathrm{F}=3,56^{* *}$, (C) Poultry manure $\mathrm{F}=3,48^{* *}$, and (D) Composting $\mathrm{F}=1,132 \mathrm{~ns}$; Dose $\mathrm{F}=3,35^{*}$; Sources $\mathrm{F}=9,42^{*}$; Dose $\mathrm{x}$ sources $\mathrm{F}=1,91^{\text {ns }}$.

Ciênc. agrotec., Lavras, v. 36, n. 6, p. 615-623, nov./dez., 2012 
Table 2 - Response surface for height increment (IH) and stem diameter increment (ID) in seedlings of physic nut as a function of days after transplanting (DAT) and doses of organic fertilizer $\left(\mathrm{L} \mathrm{m}^{-3}\right)$.

\begin{tabular}{|c|c|c|c|}
\hline \multirow{2}{*}{ Equation } & \multirow{2}{*}{$\mathrm{R}^{2}$} & \multicolumn{2}{|c|}{ Maximum point } \\
\hline & & DAT & Dose \\
\hline ------------------------------- $\quad$ Fish manure ----- & --------- & --- & \\
\hline $\mathrm{Hi}=14.9469-0.1268 \mathrm{DAT}+0.0254$ Dose $-0.00005 \mathrm{Dose}^{2}$ & $0.51 * *$ & - & 254 \\
\hline $\mathrm{Di}=-8.7769+0.4850 \mathrm{DAT}-0.0034 \mathrm{DAT}^{2}+0.0066$ Dose $-0.00002 \mathrm{Dose}^{2}$ & $0.93 * *$ & 71 & 27 \\
\hline $\mathrm{Hi}=12.5056+0.0127 \mathrm{DAT}-0.0010 \mathrm{DAT}^{2}+0.0117 \mathrm{Dose}^{-}$ & $0.56 * *$ & 6 & - \\
\hline $\mathrm{Di}=-9.2332+0.5123 \mathrm{DAT}-0.00359 \mathrm{DAT}^{2}+0.00438 \mathrm{Dose}$ & $0.91 * *$ & 71 & - \\
\hline Hi & & -- & \\
\hline $\mathrm{Hi}=4.9969+0.1815 \mathrm{DAT}-0.0016 \mathrm{DAT}^{2}-0.0088$ Dose & Ns & - & - \\
\hline $\mathrm{Di}=-6.1008+0.4015 \mathrm{DAT}-0.0028 \mathrm{DAT}^{2}-0.0072 \mathrm{Dose}$ & $0.78^{* *}$ & 71 & - \\
\hline $\mathrm{Hi}=9.62716+0.0351 \mathrm{DAT}-0.0010 \mathrm{DAT}^{2}+0.0087 \mathrm{Dose}^{-}$Composting & $0.56 * *$ & 17 & - \\
\hline $\mathrm{Di}=-7.8072+0.4461 \mathrm{DAT}-0.0031 \mathrm{DAT}^{2}+0.0025 \mathrm{Dose}$ & $0.89 * *$ & 71 & - \\
\hline
\end{tabular}

$* *$ and ns: significant at $1 \%$ and not significant, respectively.

It is noteworthy that the way of growth in height and diameter occurred at different stages; height increment occurred before 30 DAT while increase in stem diameter is more likely at approximately 71 DAT. According to Ferreira et al. (2009), stem diameter was the least responsive characteristic to change in response to container volume of physic nut seedlings after 30 days of development at the nursery. According to the same authors, six months after field planting seedling height and stem diameter values were not affected by container volume used in the nursery for seedling production.

Faster seedling growth with soil plus fish manure, composting or cattle manure can also be attributed to the fact that the organic material, plus the addition of nutrients promoted an increased ion exchange capacity, which also influences the aeration and water retention capacity, structure and soil protection, even enabling survival and interaction among microorganisms (BUSATO et al., 2009), all important substrate characteristics for plant growth.

\section{CONCLUSIONS}

Doses greater than $100 \mathrm{~L} \mathrm{~m}^{-3}$ from poultry manure mixed with clay soil for fertilizing seedlings of physic nut should be avoided. The use of other sources such as cattle manure, fish manure and composting may be used and result in increase in height, leaf area, SPAD index up to doses of $200 \mathrm{~L} \mathrm{~m}^{-3}$ manure mixed in clay soil.

\section{ACKNOWLEDGEMENTS}

To CNPq and CAPES for financial support.

\section{REFERENCES}

ARRUDA, F. P. et al. Physic nut (Jatropha curca L.) cultivation as an alternative crop for the northeast semi-arid of Brazil. Revista Brasileira de

Oleaginosas e Fibrosas, Campina Grande, v.8, p.789799, 2004.

BUSATO, J. G. et al. Guide to organic fertilization, Based on experience with soils and wastes of the North Fluminense. Programa Rio Rural, Rio de Janerio, 2009. p.14-29.

CAMARGO, R. et al. Evaluation of substrates for production of physic nut seedlings in plastic bags. Revista Trópica - Ciências Agrárias e Biológicas, Chapadinha, v.5, n.1, p.31-38, 2011.

CRUZ, C. D. Program genes: Biometrics. Editor UFV. Viçosa, 2006.

\section{EMPRESABRASILEIRADEAGROPECUÁRIA- EMBRAPA. National Research Center for Soil.}

Brazilian system of soil classification. Brasília: Embrapa Produção de Informação; Rio de janeiro: Embrapa Solos. 1999. 
FERREIRA, M. G. R. et al. Evaluation of growth of seedlings of jatropha (Jatropha curcas L.) in containers of different volumes and monitoring the development in the field. Embrapa, Porto Velho, n.107, p.4, 2009.

FERNANDES, M. S. Mineral nutrition of plants. Brazilian Society of Soil Science, Viçosa, 2006, 432p.

GONÇALVES, J. L. M. et al. Production of native species: substrate, nutrition, fertilization and shading. In: GOLÇALVES, J. L. M.; BENEDETTI, V. Forest Nutrition and Fertilization. Piracicaba, 2005. p.309-350.

LAVIOLA, B. G.; DIAS, L. A. S. Nutrient concentration in Jatropha curcas L. leaves and fruits and estimated extraction at harvest. Revista Brasileira de Ciência do Solo, Viçosa, v.32, p.19691975, Sept./Oct. 2008.

LIMA, R. L. S. et al. Substratos para produção de mudas de mamoneira compostos por misturas de cinco fontes de matéria orgânica. Ciência e Agrotecnologia, Lavras, v.30, n.3, p.474-479, maio/jun. 2006.

LIMA R. L. S. et al. Growth and nutrition of jatropha seedlings in a substrate containing urban waste compost. Revista Caatinga, Mossoró, v. 24, n.3, p.167172, jul./set. 2011.

NOVAIS, R.F.; SMYTH, T.J.; NUNES, F.N. Fósforo. In: NOVAIS, R.F. et al. Soil fertility. Brazilian Society of Soil Science. Viçosa, 2007, p. 471-550.

OLEYNIK, J. et al. Soil analysis: tables of analytical results for processing and interpretation of results. EMATER. Curitiba, (Information Technique, 31). 3. ed. 1995, 66p.

OPENSHAW, K. A review of Jatropha curcas: an oil plant of unfulfilled promise. Biomass and Bioenergy, Amsterdam, v.19, p.1-15, jul., 2000.

PIEKIELEK, W. P.; FOX, R. H. Use of a chlorophyll meter to predict sidedress nitrogen requirements for maize. Agronomy Journal, Madison, v.84, p.59-65, jul., 1992.

RUPPENTHAL, V.; CASTRO, A. M. C. Effect of urban waste compost on nutrition and yield of gladiolus.

Revista Brasileira de Ciência do solo, Viçosa, v.29, n.1, p.145-150, fev., 2005.
SATURNINO, H. M. et al. Culture of jatropha ( Jatrofa curcas L. ). Informe Agropecuário, Belo Horizonte, v.26, n.229, p.44-78, mai., 2005.

SAMPAIO, E. V. S. B.; OLIVEIRA, N. M. B;

NASCIMENTO, P. R. F. Efficiency of organic fertilization with cattle manure and Egeria densa. Revista Brasileira de Ciência do Solo, Viçosa, v. 31, p.995-1002, set./out., 2007.

SEDIYAMA, M. A. N. et al. Fermentation of pig manure for use as an organic fertilizer. Revista Brasileira de Engenharia Agrícola e Ambiental, Campina Grande, v.12, n.6, p.638-644, set., 2008.

\section{SEVERINO, L. S.; LIMA, R. L. S.; BELTRÃO, N. E. M.} Composição Química de Onze Materiais Orgânicos Utilizados em Substratos para Produção de Mudas. Comunicado técnico 27, Embrapa Algodão, Campina Grande, n. 278, p. 5, ago. 2006.

SEVERINO, L. S.; DO VALE, L. S.; BELTRÃO, N. E. M. A simple method for measurement of Jatropha curcas leaf area. Revista Brasileira de Oleaginosas Fibrosas, Campina Grande, v.11, n.1, p.9-14, jan./abr. 2007.

SMEAL, D.; ZHANG, H. Chlorophyll meter evaluation for nitrogen management in corn. Communications in Soil Science and Plant Analysis, New York, v.25, p.1495-1503, 1994.

SOBRINHO, W. N. et al. Nutrients accumulation in plants of millet in function of organic and mineral fertilization. Caatinga, Mossoró, v.22, n.3, p.107-110, jul/ set., 2009.

\section{STORCK, L.; GARCIA, D. C.; LOPES, S. J. Trial plant.} Santa Maria, 2000, 198p.

SUBRAMANIAN, K. A. et al. Utilization of liquid biofuels in automotive diesel engines: an Indian perspective. Biomass \& Bioenergy, Amsterdam, v.29, p.65-72, fev., 2005.

TEDESCO, M. J. et al. Analysis of soil, plants and other materials. Porto Alegre,1995, 174p.

TOMÉ JÚNIOR., J. B. Manual for the interpretation of soil analysis. Bookstore and Publisher Agropecuária, Guaíba,1997.247p. 
TOMINAGA, N. et al. Cultivation of Jatropha for biodiesel production. Technology Center Productions, Viçosa, 2007, 220p.
UNITED STATES DEPARTMENT OF AGRICULTUREUSDA. Keys to soil taxonomy. 7.ed. Washington, 1996, $664 \mathrm{p}$. 